\title{
Production of minerals paste from phosphates sludge
}

\author{
Producción de pasta mineral a partir de lamas fosfáticas \\ R.H. Olcay B. ${ }^{1} \quad$ C.A. Hernández O. ${ }^{1} \quad$ G.E.S. Valadão ${ }^{2} \quad$ A.P. Chaves $^{3}$ \\ Recibido 02 de febrero de 2018, aceptado 23 de diciembre de 2018 \\ Received: February 02, 2018 Accepted: December 23, 2018
}

\begin{abstract}
RESUMEN
El método más utilizado para la disposición de los relaves fosfáticos es vía tranque convencional de relaves. La disposición de relaves en forma de pasta mineral presenta ventajas sobre la disposición convencional. El objetivo de este trabajo fue la producción y caracterización de pastas minerales desde lamas fosfáticas utilizando un espesador en escala de laboratorio. Los principales resultados fueron: a) peso específico del material sólido: $2,61 \mathrm{~g} / \mathrm{cm}^{3}$; b) lama $100 \%<30 \mu \mathrm{m}$; c) el análisis químico reveló presencia principal de magnesio, calcio, fósforo y oxígeno; d) el análisis mineralógico indicó predominancia de calcita y dolomita; e) la muestra presentó elevado valor de área superficial específica de $0,976 \mathrm{~m}^{2} / \mathrm{g}$; f) en los ensayos de espesamiento el tiempo requerido para el punto máximo de compresión sin floculante fue $7.200 \mathrm{~s} ; \mathrm{g}$ ) los ensayos de sedimentación continua con recirculación y floculante aumentaron alrededor de $6 \%$ sólidos en la descarga; h) el perfil de concentración del sedimento exhibe una transición de pulpa de alta densidad a pasta mineral entre 55\% y 58\% sólidos; i) respecto a la generación de flóculos el sistema RGF presentó una descarga más densa de concentración de sólidos en todo el rango operacional; j) el sistema de rastras presentó un aumento alrededor de $7 \%$ sólidos en la descarga; k) con las mejores condiciones operacionales fueron obtenidas pastas minerales de $70 \%$ sólidos; 1 ) el esfuerzo de cedencia tuvo valores superiores a $80 \mathrm{~Pa}$ desde $65 \%$ de sólidos característica de una pasta mineral.
\end{abstract}

Palabras clave: Espesamiento, pasta mineral, reología.

\begin{abstract}
The most used method for the disposal of phosphates tailings is through of tailing dams conventional. The tailing disposal in the form of mineral paste has advantages compared with the disposal conventional. The objective of this work is the production and characterization of mineral pastes from phosphates sludges using a thickener in laboratory scale. The main results were: a) the specific gravity of solid material: $\left.2.61 \mathrm{~g} / \mathrm{cm}^{3} ; b\right)$ sludge $\left.100 \%<30 \mu \mathrm{m} ; c\right)$ the chemical analysis indicated the principals presence of magnesium, calcium, phosphorus and oxygen; d) the mineralogy detected the presence calcite and dolomite as main phases; $e$ ) sample showed high value of the superficial specific area through Blaine method was $0.976 \mathrm{~m}^{2} / \mathrm{g} ; \mathrm{f}$ ) the thickening tests time required for maximum compression point of phosphate mud without the use of flocculant was 7,200 s; $g$ ) the tests continuous sedimentation using recirculation and the use of flocculant selected increased by approximately $6 \%$ solids in the underflow; h) a transition stage of high
\end{abstract}

1 Metallurgy Engineering Department. Faculty of Engineering and Architecture. Arturo Prat University. Av. Arturo Prat \# 2120. Iquique, Chile.

E-mail: rolcay@unap.cl; chernand@unap.cl

2 Mining Engineering Department. Federal University of Minas Gerais. Av. Antonio Carlos \#6627. Belo Horizonte, Brazil. E-mail: gvaladao@demin.ufmg.br

3 Department of Mining and Petroleum Engineering. Polytechnic School of the São Paulo University. Av. Professor Mello Moraes \#2373. São Paulo, Brazil. E-mail: apchaves@usp.br

* Corresponding Author: rolcay@unap.cl, or rolcay@gmail.com 
slurry density to mineral paste in the range between $55 \%$ and $58 \%$ solids was observed; i) concerning to generations of flocs, the FGR system presented a discharge more dense of solids concentration in all operational range; $j$ ) an increase of around $7 \%$ solids in the underflow was noted using rake system; $k$ ) with the best operational conditions in the equipment were obtained paste minerals of $70 \%$ solids; l) the yield stress of phosphate sludge showed values greater than 80 Pa from $65 \%$ solids characteristic of mineral paste.

Keywords: Thickening, mineral paste, rheology.

\section{INTRODUCTION}

The beneficiation of phosphate ores generates large quantities of tailing and by-products. For example in Florida the phosphate mining and beneficiation produces about 100,000 tons of waste clays are currently produced each day. There are more than 85,000 acres of phosphatic clay ponds and clayfilled mine cuts, with approximately 5,000 acres of additional ponds created each year by ongoing phosphate mining and beneficiation. Waste clay disposal represents one of the most challenging problems for the phosphate industry. Because of their colloidal nature and ultrafine size $(91.5 \%$ by weight -325 mesh or $44 \mu \mathrm{m}$ ), the phosphatic clays are very stable in water suspensions and settle extremely slowly [1].

Large areas for disposal in conventional dam system are required. The disposal of mineral tailings in the form of mineral paste is an alternative technology that may allow better utilization of the disposal areas, provision of greater stability of disposal, greater reuse of process water, operational optimization and other factors [2].

The consolidation of phosphatic clays to a state suitable for reclamation and reuse of the land may take a decade or more, and suitability for support of constructed facilities may not occur at all. Efforts to solve the problems associated with phosphatic clay disposal and reclamation have included testing of mechanical, electrical, biological, and chemical processes. These efforts have included the addition of coagulants and flocculants, mechanical dewatering, the use of enzymes and bacteria and various other methods of thickening and stabilization [3].

The mineral paste can be defined as a system of fine particles which is presented as a homogenous fluid, in which no occurs particle size segregation of particles, and which if disposed smoothly on a stable surface, no present a significant water drainage [4-5]. However, can be defined as a non-settling, non-segregation, homogeneous suspension with minimal water release [3].

The characteristics of the behavior of the mineral paste are due to slurry densification in solids from a certain percentage of solids by weight. As a result, higher angles of repose can be achieved for example depend the concentration of the sludge in laboratory scale was obtained values between 4 and 16 degrees [2]. This represents a significant gain in terms of volumes to be arranged in the same area. Among the main properties of a mineral paste include: viscosity, yield stress, consistency and the angle of repose [6-8].

A paste does not obey the rules of flow for a Newtonian fluid. This non-Newtonian character results in a rheology that changes with exposure to different shearing rates and times during thickening, pumping, flowing in a pipeline, and deposition. For many mineral beneficiation tailings pastes, viscosity changes with the shearing rate [3].

The use of thickeners to produce mineral paste is already practiced in several countries such as Australia for disposal of "red mud" [9-10], Canada [11] and the United States for disposal of phosphatic clays [1-3]. In Chile and Peru is an important issue mainly due to lower availability of water in arid regions. Mining of Brazil has also a strong focus because of the need for the application of new technologies that allow for greater reuse of water used in the process and tailings disposal with higher concentrations of solids.

HiDensity and DeepBed paste thickeners were developed to produce higher yield stress underflow solids. The higher the underflow solids, the higher the yield stress produced. Higher density underflow 
solids reduce water losses or water usage in many instances. This must be tempered with consideration to the underflow rheology [12].

Yield stress, which is defined as the minimum stress that must be applied in order to induce flow, is a key design parameter in the industrial application of surface disposal of thickened tailings (sometimes termed paste) [13]. Several studies relate to the yield stress with a colloidal stability and surface characteristics of the particles [14-16].

Floc strength is a particularly important operational parameter in solid/liquid separation techniques for the efficient removal of aggregated particles. Smaller particles will generally settle more slowly than larger particles of similar density [17].

The settling rate measurements indicate an inverse relations between floc size and density. The reduced floc density with increasing size is usually attributed to the incorporation of fluid into the floc structure [18-19]. Floc strength is directly related to floc structure and is, therefore, highly dependent upon the floc formation process [17].

The measured apparent yield stress is dependent on the operation procedure and test apparatus due to the materials complex continuous three-dimensional network microstructure. The problems associated with measuring the rheology of structured fluids can be overcome by using a vane.

The vane consists of four or more blades that form a cross shape at the end of a central shaft and can be inserted into the sample with minimal disturbance of the microstructure [20]. The vane is primarily used to determine the yield stress of structured systems and detailed reviews on this and other methods to characterise the yield stress can be found in several articles [7-21-22].

Unlike a slurry, which is basically a liquid, a paste will hold its shape to a degree determined primarily by the solids concentration. This property is a defining characteristic of a paste that promotes increasingly solid-like behavior as the material becomes more concentrated.

Yield stress, which is the pressure required to make the paste flow, arises from a unique property of non-newtonian fluids. The bond formation between fine particles through electrostatic and structural interactions produces a continuous network that breaks only when a certain pressure is applied, which is the yield stress. The coarser particles are inhibited from settling by the fine particle network acting like a net to hold solids in suspension. This phenomenon is responsible for the nonsettling and non-segregation behavior of pastes. Shearing introduces energy that disrupts the bonding between fine particles, causing a change in viscosity. Yield stress is dependent on many parameters such as particle size, temperature, mineralogy, $\mathrm{pH}$, and solids concentration [3].

The yield stress of tailings increases exponentially with increasing solids concentration so a small change in concentration can result in a large change in the yield stress [13], consequently, control of material consistency in waste disposal operations is critical [23-24]. Various studies make a relationship of yield stress with the solids concentration of tailings [25-29].

The yield stress is characterized principally for: i) the shear stress required to initiate significant flow, ii) below its yield stress a material will behave elastically, iii) crucially important in preparation, transport and deposition of thickened tailings [30]. Figure 1 shows, in qualitative character, the yield stress as a function of percent of solids.

The objective of this work is show other alternative of tailings disposal through the production, characterization and analyses rheological of mineral pastes from phosphates sludges using a thickener in laboratory scale considering the possible disposal of these materials because that this technique is few used actually in Latin American mining.

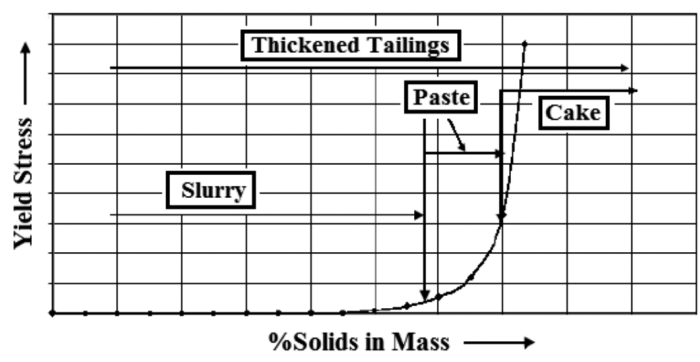

Figure 1. Yield stress as a function of the percentage of solids [30]. 


\section{METHODOLOGY}

\section{Sample Mineral}

The sample mineral used represent sludge obtained from the beneficiation plant of phosphate ore of Brazil. The Table 1 presents the different techniques and equipments used to determine the physical and chemical characterization of the mineral sample.

\section{Settling Tests}

The settling tests were carried out using graduated cylinders ( $2 \mathrm{~L}$ ) at $10 \%$ solids in mass for preliminary determination of the minimum residence time necessary to obtain slurry with higher density.

The selection of the best performing flocculants was effected in graduated cylinders $(0.5 \mathrm{~L})$ at $10 \%$ solids in mass, value corresponding to the industrial plant of beneficiation.

The flocculants evaluated are the types: cationic, anionic and non-ionic prepared at concentrations of $0.1 \% \mathrm{~W} / \mathrm{V}$ and diluted to $10 \% \mathrm{~V} / \mathrm{V}$. The flocculation was carried out in a graduated cylinder of $2 \mathrm{~L}$ using the manual agitator, in upward and downward movements for mixing the slurry with the polymer for $5 \mathrm{~s}$ based in previous works [8-31].

The flocculant which presented the best performance was selected for thickening tests in laboratory scale.

\section{Laboratory Mineral Paste Thickener}

This equipment is made of acrylic with three cylindrical modules having total height of $1.8 \mathrm{~m}$ with $0.1 \mathrm{~m}$ of diameter and maximum slurry volume of $10 \mathrm{~L}$. The rake system, with low speed rotation, can be used. Sampling and recirculation of slurry can be performed by means of a series of lateral nozzles. The underflow discharge of the mineral paste is carried out on the bottom of the equipment and the overflow exits from the top. The continuous feed operation was performed by using peristaltic pumps. The Figure 2 shows the general view of the assembly of the equipment.

\section{Static Mixer and Floc Generator Reactor}

The system of static mixer consists of a tube of carbon steel with $0.0508 \mathrm{~m}$ internal diameter and $0.30 \mathrm{~m}$ length with a series of baffles positioned to stimulate increased contact between slurry and polymer. Figure 3 shows the system used with the static mixer.

The Figure 4 shows the floc generator reactor system (FGR) used in the mineral paste thickener.

The floc generator reactor consists in a transparent polyurethane tube with an internal diameter of $0.0127 \mathrm{~m}$ wrapped on the outside of a fixed column of polyvinyl chloride with an internal radius of $0.1 \mathrm{~m}$ and length of $1.2 \mathrm{~m}$.

The purpose of the two devices is to operate in order to improve the interaction polymer/mineral particle allowing the most appropriate flocculation.

\section{Mineral Paste Thickener Tests}

All the tests in the mineral paste thickener aimed to obtain the maximum percentage of solids possible in the underflow. The best operational conditions found were the followings: total time in continuous operating of $180 \mathrm{~min}$, slurry feed at $10 \%$ solids in mass, dosage of the selected flocculant $80 \mathrm{~g} / \mathrm{t}$, total volume of operation $10 \mathrm{~L}$, use of the two types of mixers slurry/flocculant (SM and FGR), recirculation of the slurry at different points of the compaction zone, rake rotation $5 \mathrm{rpm}$ (when used).

The solid concentration profile along the settled layer was determined by use of lateral nozzles.

Table 1. Techniques and equipments used to characterize the mineral sample.

\begin{tabular}{|l|l|l|}
\hline \multicolumn{1}{|c|}{ Property } & \multicolumn{1}{c|}{ Technique Used } & \multicolumn{1}{c|}{ Required Equipment } \\
\hline Specific gravity & Simple pycnometry and gas & Pycnometer and gas \\
\hline Size distribution & Centrifugal classification and Laser diffraction & Cyclosizer and Sympatec \\
\hline Specific area & Adsorption of nitrogen and air of permeability & BET adsorption system and Blaine apparatus \\
\hline Yield stress & Rheometry & Haake rheometer \\
\hline Chemical composition & X-ray flourescence & Dispersive X-ray spectrometer \\
\hline Mineral composition & X-ray diffraction & X-ray spectrometer \\
\hline
\end{tabular}




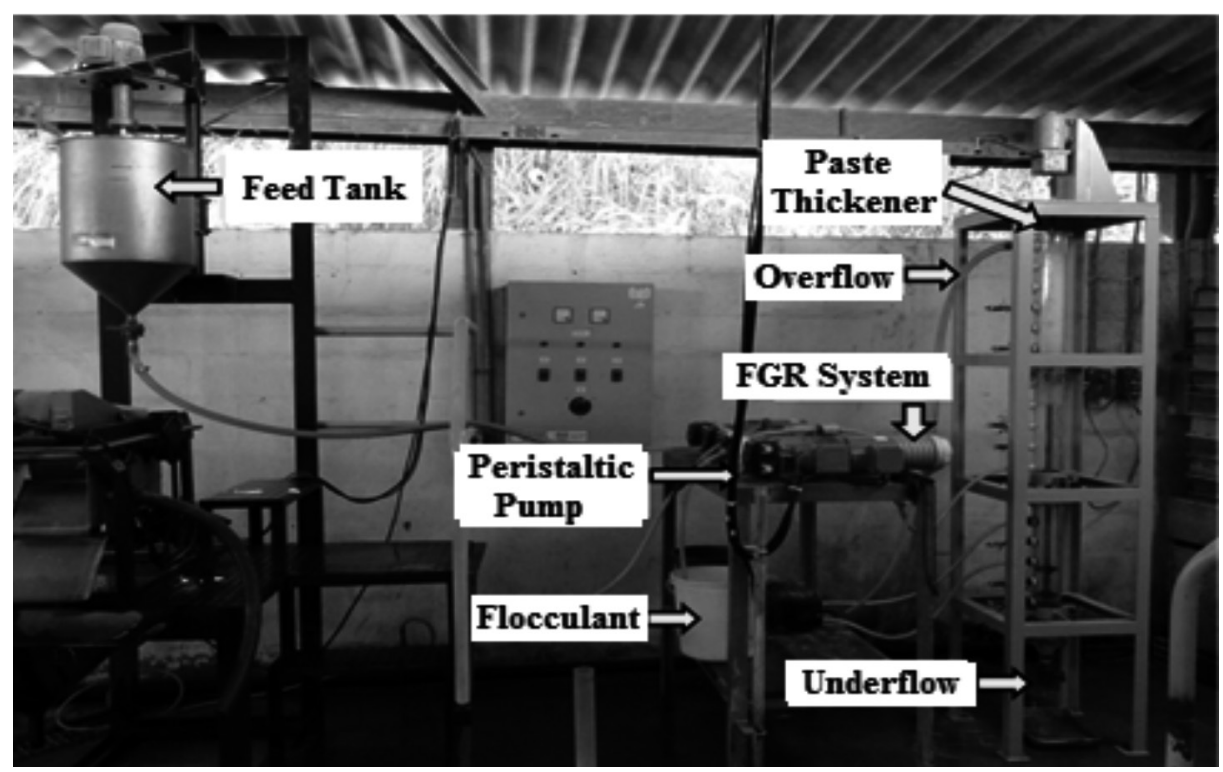

Figure 2. General view of operational assembly of the mineral paste thickener [2].

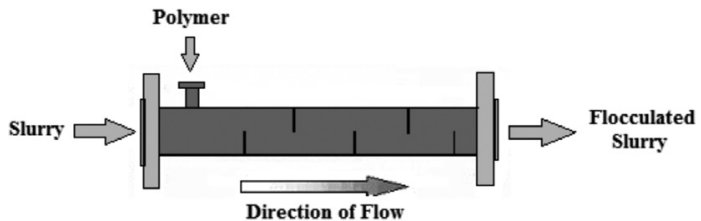

Figure 3. Static Mixer (SM) for feeding slurry with polymer [2].

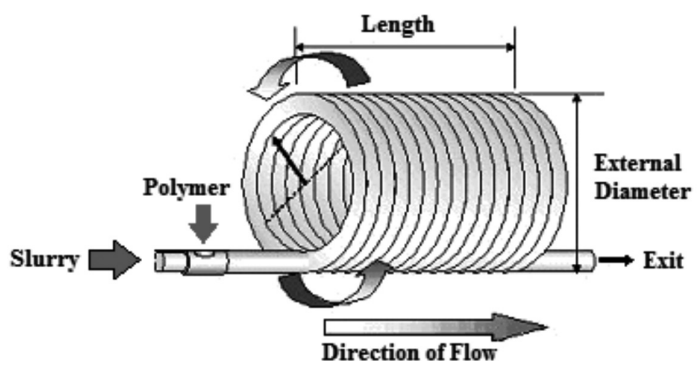

Figure 4. Floc Generator Reactor (FGR) for feeding slurry with polymer [32].

\section{Yield Stress Measurements}

Measurements of yield stress were performed on slurries and minerals pastes using a Haake digital rheometer with interface for constant sending data to the computer. Figure 5 shows the rheometer utilized.

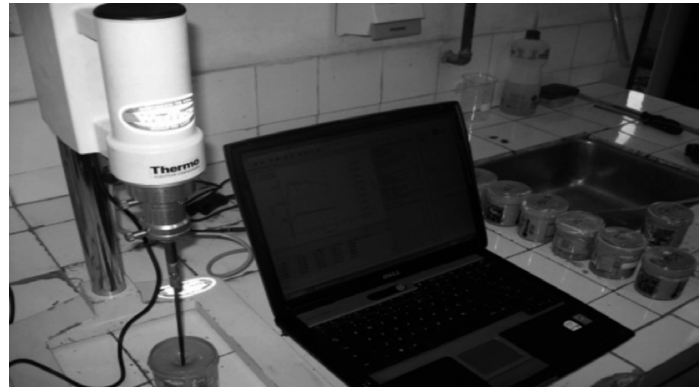

Figure 5. Haake rheometer, model VT-550 with interface to the computer.

Two models were used to determine the yield stress of the slurries and minerals pastes: The model of Break-Through and Bingham with a duration of approximately 300 seconds for each solids concentration. In the first model, the sensor helical of the viscometer turned slowly measuring the resulting drag force. The turning force increased until reaching a point maximum decreasing gradually until stop reading.

The point maximum was used as a measure of the yield stress. The second model consists in generating a flow curve by placing the samples in a series of shear stress, which are obtained by applying the slurries and minerals pastes in different speeds of rotation through the helical sensor. 
The data generated by the flow curve were interpreted using the Bingham model, which extrapolates the data back to zero shear.

\section{RESULTS}

\section{Mineral Sample Characteristics}

The specific weight values obtained by simple pycnometry (SP) and gas (GP) are presented in the Table 2. Based in the data historical of the industrial plant for comparative effect the specific gravity obtained by simple pycnometry was considered for calculation as guidelines of the tests [2]. The standard desviation for measurement of the simple pycnometry was $1.23 \%$.

Table 2. Specific weight values obtained by simple pycnometry and gas.

\begin{tabular}{|l|c|}
\hline \multicolumn{1}{|c|}{ Technique Used } & Specific Weight $\left(\mathbf{g} / \mathbf{c m}^{\mathbf{3}}\right)$ \\
\hline Simple pycnometry & 2.61 \\
\hline Gas pycnometry & 3.06 \\
\hline
\end{tabular}

The particle size distribution of the mineral sample is shows in Figure 6. The material is very fine: $100 \%$ less than $30 \mu \mathrm{m}$. The value of the median size $\left(\mathrm{d}_{50}\right)$ is about $4.76 \mu \mathrm{m}$. The difference between the curves reflects the measurement parameters of each equipment: the size of each particle determined by the laser diffractometer is the arithmetic average of the three major dimensions of this particle, and the size measured by the cyclosizer is the hydraulic diameter of the particle.

The chemical composition of the mineral samples were obtained by X-ray fluorescence. The results

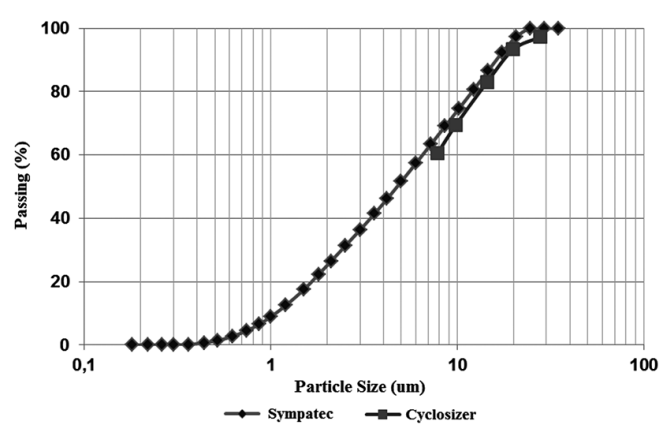

Figure 6. Size distribution of the mineral sample. are shown in Table 3, in which indicating the predominance of $\mathrm{CaO}, \mathrm{MgO}, \mathrm{SiO}_{2}, \mathrm{P}_{2} \mathrm{O}_{5}$ and $\mathrm{Fe}_{2} \mathrm{O}_{3}$ with the presence of small quantities of $\mathrm{Al}_{2} \mathrm{O}_{3}, \mathrm{~K}_{2} \mathrm{O}$, $\mathrm{SO}_{3}$ and $\mathrm{Ti}_{2} \mathrm{O}_{3}$. The loss on ignition (LOI) was of $37.5 \%$ principally due to the presence of carbonates.

Table 3. Chemical composition of the mineral sample obtained by X-ray fluorescence.

\begin{tabular}{|c|c|c|c|}
\hline Compound & $(\boldsymbol{\%})$ & Compound & (\%) \\
\hline $\mathrm{CaO}$ & 48.22 & $\mathrm{Al}_{2} \mathrm{O}_{3}$ & 0.31 \\
\hline $\mathrm{MgO}$ & 4.60 & $\mathrm{~K}_{2} \mathrm{O}$ & 0.11 \\
\hline $\mathrm{SiO}_{2}$ & 3.03 & $\mathrm{SO}_{3}$ & 0.87 \\
\hline $\mathrm{P}_{2} \mathrm{O}_{5}$ & 3.34 & $\mathrm{Ti}_{2} \mathrm{O}_{3}$ & 0.11 \\
\hline $\mathrm{Fe}_{2} \mathrm{O}_{3}$ & 1.54 & $\mathrm{LOI}$ & 37.5 \\
\hline
\end{tabular}

The analysis X-ray diffraction was by the method of Rietveld that indicated as the main mineralogical phases: $\mathrm{CaCO}_{3}$ (calcite) and $\mathrm{CaMg}\left(\mathrm{CO}_{3}\right)_{2}$ (dolomite). It was also detected the presence of $\mathrm{K}_{2} \mathrm{O} \cdot 6 \mathrm{MgO} \cdot \mathrm{Al}_{2} \mathrm{O}_{3} \cdot 6 \mathrm{SiO}_{2} \cdot 2 \mathrm{H}_{2} \mathrm{O}$ (phlogopite) and $\mathrm{Fe}_{3} \mathrm{O}_{4}$ (magnetite). The Table 4 shows the specific superficial area determined by BET and Blaine techniques. It was observed the significant difference between the values, as expected. However, the adsorption isotherm obtained by the BET method showed how type III, does not represent the monolayer formation necessary for adequate evaluation.

Table 4. Specific Superficial Area.

\begin{tabular}{|c|c|}
\hline Technique Used & Specific Superficial Area $\left(\mathbf{m}^{2} / \mathbf{g}\right)$ \\
\hline BET & 1.972 \\
\hline Blaine & 0.976 \\
\hline
\end{tabular}

\section{Settling Tests}

The Figure 7 shows the settling curve obtained by using graduated cylinder of $2 \mathrm{~L}$ for slurry at $10 \%$ solids without use of flocculant. The maximum compression point has been reached to values greater than 7,200 s with a settling rate of 0.0119 $\mathrm{cm} / \mathrm{s}$, which can be seen as slow when compared metallic ore tailings.

\section{Selection and Dosage of Flocculant Tests}

The settling rate of de slurry with different dosages of flocculant was determined in the initial phase of the zone free settling through relationship the 


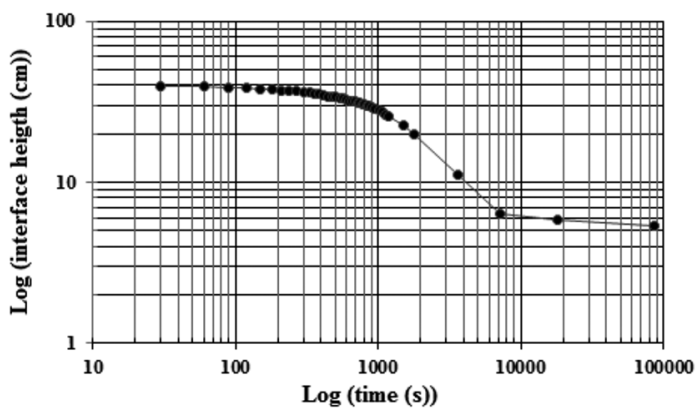

Figure 7. The height of the interface versus time both in logarithmic scale.

height of the interface $(\mathrm{cm})$ and the time (s) of the experimental data from the setting curve. The Table 5 presents the results of the settling rate tests carried out in the presence of cationic, anionic and non-ionic polymers that for comparatives purpose was selected a dosage of $50 \mathrm{~g} / \mathrm{t}$.

The flocculant selected was the $\mathrm{CF} 3$ for subsequent tests. The settling rate reached was $0.831 \mathrm{~cm} / \mathrm{s}$ at the dosage of $80 \mathrm{~g} / \mathrm{t}$. It represents a significant increase ( 70 times) of the settling rate when compared with the test without addition of flocculant. The Figure 8 indicates the settling rates obtained at various dosages of this flocculant.

Thickening with Recirculation of Slurry Tests The tests with recycle of slurry (10\% solids in mass) were performed between zones sedimentation denominated as transition and compression with the addition of $80 \mathrm{~g} / \mathrm{t}$ of cationic flocculant (CF3) reaching a total volume of $10 \mathrm{~L}$.

The time residence of the samples was of 15 min (900 s) approximately. The combinations of recirculation and thickening obtained are shows in the Figures 9 and 10.

Table 5. Settling rate tests for cationic (CF), anionic (AF), and non-ionic flocculants (NIF).

\begin{tabular}{|c|c|c|}
\hline $\begin{array}{c}\text { Settling Rate } \\
\mathbf{C F}(\mathbf{c m} / \mathbf{s})\end{array}$ & $\begin{array}{c}\text { Settling Rate } \\
\mathbf{A F}(\mathbf{c m} / \mathbf{s})\end{array}$ & $\begin{array}{c}\text { Settling Rate } \\
\mathbf{N I F}(\mathbf{c m} / \mathbf{s})\end{array}$ \\
\hline $\mathrm{CF} 1 / 0.187$ & $\mathrm{AF} 1 / 0.241$ & $\mathrm{NIF} 1 / 0.153$ \\
\hline $\mathrm{CF} 2 / 0.263$ & $\mathrm{AF} 2 / 0.185$ & $\mathrm{NIF} 2 / 0.126$ \\
\hline $\mathrm{CF} 3 / 0.480$ & $\mathrm{AF} 3 / 0.125$ & $\mathrm{NIF} 3 / 0.087$ \\
\hline $\mathrm{CF} 4 / 0.354$ & $\mathrm{AF} 4 / 0.095$ & $\mathrm{NIF} 4 / 0.195$ \\
\hline $\mathrm{CF} 5 / 0.194$ & $\mathrm{AF} 5 / 0.106$ & $\mathrm{NIF} 5 / 0.163$ \\
\hline
\end{tabular}

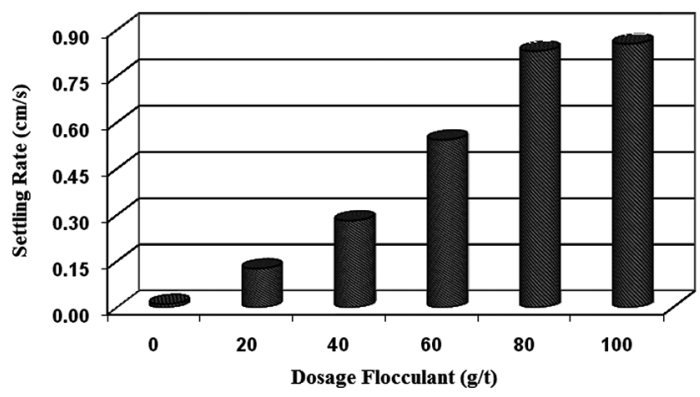

Figure 8. Settling rate of the slurry as a function of dosage of cationic flocculant (CF3).

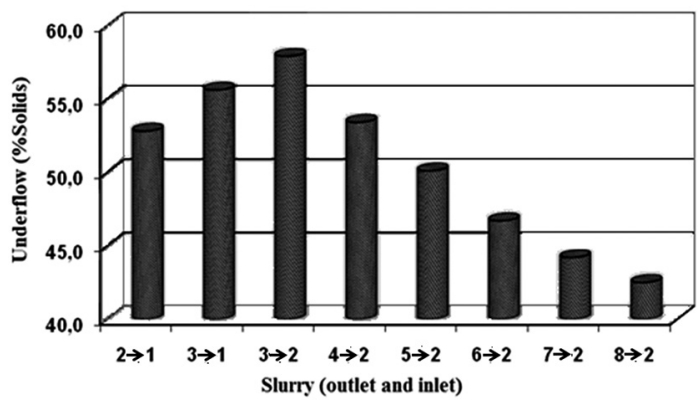

Figure 9. Percentage of solids in weight of the underflow of thickener as a function of the combinations of nozzles (exit and entry).

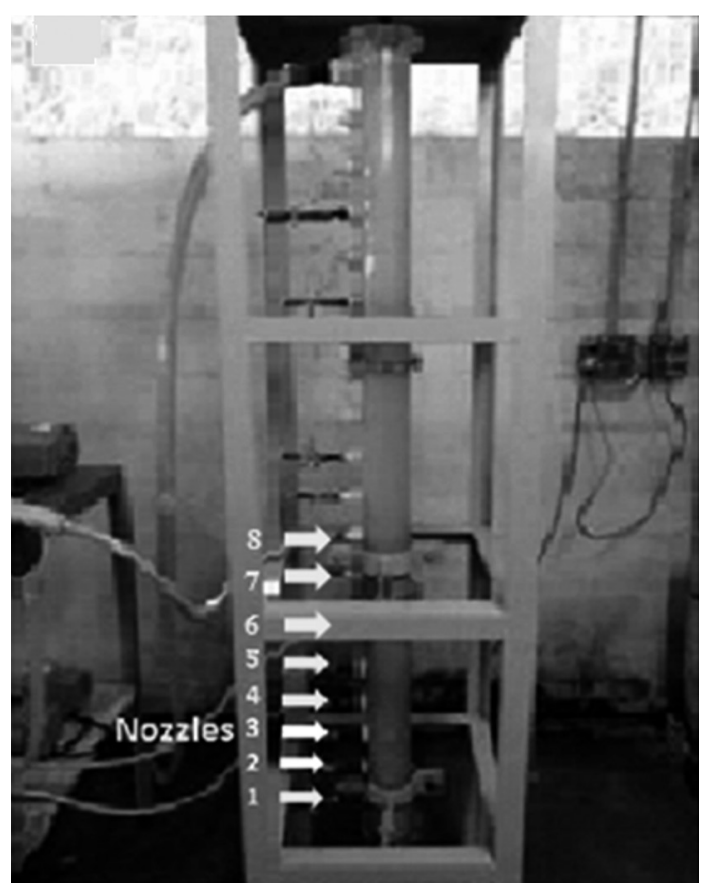

Figure 10. View of the positions of the nozzles in the thickener. 
It was observed that the best conditions of operation with continuous recirculation of the slurry was from the nozzle 3 to the nozzle 2 reaching a value of $57.9 \%$ of solids in mass in the underflow. It was evidenced that the recirculation of the slurry affects the concentration of solids in the discharge of the thickener. In the compression zone from the diluted region to concentrated region improve the concentration of solids in the discharge.

\section{Static Mixer and the Flocs Generator Reactor System Tests}

The Figure 11 shows the percentage of solids in mass obtained in the underflow as a function of operating time for static mixer (SM) and floc generator reactor system (FGR) in presence of $80 \mathrm{~g} / \mathrm{t}$ of flocculant.

The best condition was obtained using FGR system for 60 minutes of continuous operation. It was reached $64.2 \%$ of solids in mass that can be considered attractive for industrial use.

\section{Solid Concentration Profile}

The Figure 12 shows the solids concentration profile considering the use of static mixer and floc generator reactor system, with addition of flocculant CF3 $(80 \mathrm{~g} / \mathrm{t})$.

The best result was $65.4 \%$ solids in mass by using the FGR system, probably because the formation of structure flocs of this system is less aggressive than the static mixer so it generates a more compact floc with a less porous network favorable to the higher concentration of solids in the discharge due to the lower water retention. For the value of $65 \%$ solids

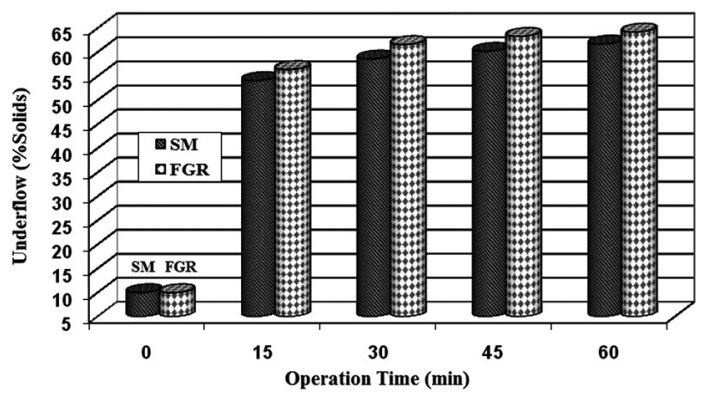

Figure 11. Percentage of solids in mass obtained in the underflow as a function of operating time for SM and FGR with $80 \mathrm{~g} / \mathrm{t}$ of flocculant.

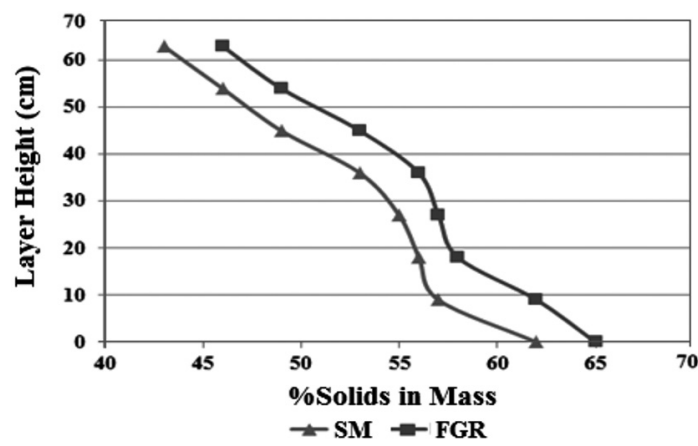

Figure 12. Profile of concentration on solids in mass, considering the use of SM and FGR.

in mass it is appreciated paste formation because the higher consistency of the mixture solid/liquid. It was observed a transition region in the range comprised between $55 \%$ and $58 \%$ solids in mass, where the solid concentration increasing takes place more slow because, probably, to formation of the flocs network more homogenous, stable and dense. It can be also noted that for percentages larger than 55\% solids in mass, approximately, occurs the formation of high density slurry for subsequent production of mineral paste.

\section{Rake Tests}

The main operational parameters for the rake tests are indicated in the Table 6.

The percentages of solids in mass obtained in the underflow in function operational time for the best conditions found in the production mineral paste with and not use of the rakes system are shows in the Figure 13.

According to the Figure 13 the use of rake system influenced positively in the increasing of solids concentration in the underflow. This fact is probably due to decrease of empty spaces and or filled by the water that are present in the structure. Values

Table 6. Main parameters in the rake tests.

\begin{tabular}{|c|c|c|}
\hline $\begin{array}{c}\text { \%Solids } \\
\text { in feed }\end{array}$ & $\begin{array}{c}\text { Dosage } \\
\mathbf{C F 3}(\mathbf{g} / \mathbf{t})\end{array}$ & $\begin{array}{c}\text { Recirculation } \\
\text { slurry }\end{array}$ \\
\hline 10 & 80 & 3 to 2 \\
\hline Type mixer & Operation time (min) & RPM rake \\
\hline FGR & 180 & 5 \\
\hline
\end{tabular}




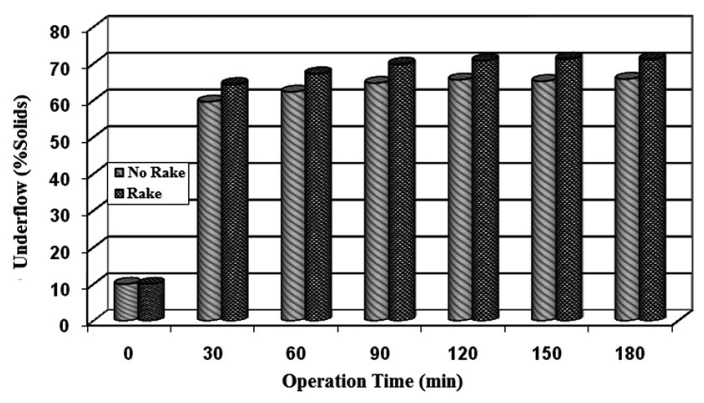

Figure 13. Percentage of solids in mass of the underflow in function of operation time with and not use the of rakes system.

achieved in the best operation condition were around $70 \%$ solids in mass after 120 min of continuous operation.

\section{Yield Stress of the Slurry and Mineral Pastes Produced by Thickener}

For the meditions was used a rotational rheometer with a sensor of immersion trough vane method. Figure 14 shows the values of the yield stress obtained by the models of Break-Through and Bingham from different slurries and minerals pastes generated through the thickener developed.

It was observed that the material becomes as mineral paste from $65 \%$ of solids in mass with initial values of the yield stress around $80 \mathrm{~Pa}$, this values confirmed the presence of paste mentioned in the Figure 12. Figure 15 presents a preliminary hypothetical comparison for the use of conventional dam and disposal in the form of mineral paste considering a flow of about $30 \mathrm{t} / \mathrm{h}$ dry basis for a period of one month.

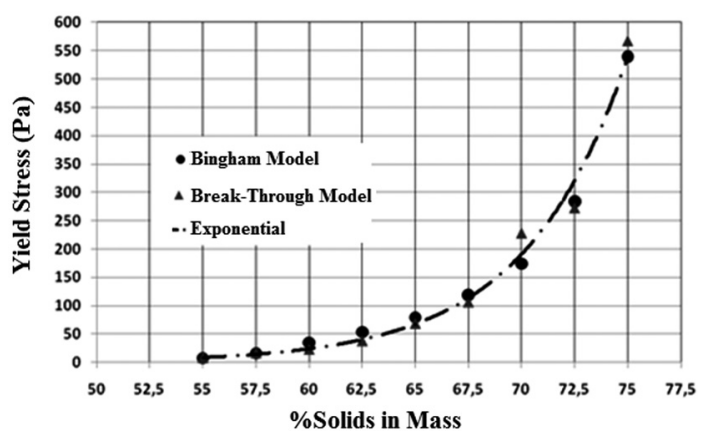

Figure 14. Yield stress as a function of the thickening of phosphate sludge.

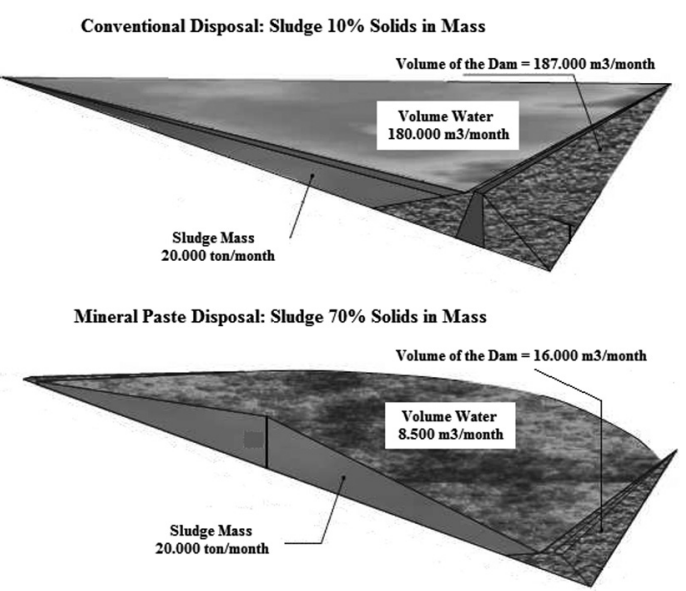

Figure 15. Comparison of areas for conventional disposal and mineral paste of phosphate sludge [Adaptation, 33].

Considering as base to the determination of disposal volume it was the density and mass of the phosphate sludge in state of slurry and paste respectively. It can be seen from the Figure 15 that conventional dam would require a volume of approximately $187,000 \mathrm{~m}^{3} /$ month for disposal of phosphate sludge "untreated". In the case of disposal of the phosphate sludge in form of mineral paste are required around $16,000 \mathrm{~m}^{3} /$ month of volume of the dam, in other words, is required a total volume for dam of approximately 12 times smaller, decreasing thereby significantly the area required for the disposal, thus increasing the life's dam around one year. The use of mineral paste enables the reuse of approximately $170,000 \mathrm{~m}^{3} /$ month of water coming directly from the overflow of the equipment producer of mineral paste. On the other hand, the conventional disposal pumping systems are usually required to improve water recovery and recirculation.

\section{CONCLUSIONS}

The phosphate slurry had particle size quite thin with an average size of $4.76 \mu \mathrm{m}$ and high specific superficial area $0.976 \mathrm{~m}^{2} / \mathrm{g}$. The predominant mineralogical species in the sample are calcite and dolomite.

The minimum time required to reach the point of maximum compression of the slurry was greater than 7,200 s. The flocculant selected is of cationic type in dosage fixed of $80 \mathrm{~g} / \mathrm{t}$. The best operating 
condition in the tests of recirculation of the slurry in the compression zone of the sludge was from the nozzle 3 to the nozzle 2 obtaining high density values around $58 \%$ solids in mass.

The use of floc generator reactor system in the feed system of slurry with flocculant presented a better efficiency than the static mixer probably because that static mixer presents higher energy of dissipation what generate flocs networks more porous and unstable that entails yet higher entrapment of water in the network. It was observed in the concentration profile that there is a transition region in the range between 55\% and 58\% solids in mass, where the increase of the percentage of solid in mass is increased more slowly.

The use of rake system influenced favorably the concentration of solids in the underflow maybe for the liberation of trapped water in the flocs network. In the best operational conditions values of $70 \%$ solids in mass were obtained for $180 \mathrm{~min}$ of continuous operation.

The phosphate sludge appears as mineral paste from of $65 \%$ solids in mass, approximately, with initial values of yield stress about $80 \mathrm{~Pa}$, which can be considered acceptable for the transport by pumping of these tailings.

The disposal of phosphate sludge in the form of mineral paste would require a volume of dam approximately of 12 times lower when compared with the conventional dam disposal, thus increasing the life operational of the dam. The use of the equipment producer of mineral paste increases operational flexibility to reuse water of process directly since the unit mineral processing, with a capacity of approximately $170,000 \mathrm{~m}^{3} /$ month.

\section{REFERENCES}

[1] D. Tão, B.K. Parekh and R. Honaker. "Development and Pilot-Scale Demonstration of Deep Cone Paste Thickening Process for Phosphatic Clay Disposal". University of Kentucky - Florida Institute of Phosphate Research, pp. 1-151. 2008.

[2] R.H. Olcay. 2012. "Desenvolvimento de Equipamento Produtor de Pasta Mineral Para Aproveitamento dos Rejeitos das
Lamas Calcárias e Diminuição do Impacto Ambiental". Belo Horizonte. Tese de Doutorado, CPGEM-UFMG. URL: https:// www.ppgem.eng.ufmg.br/diss.php

[3] G.B.Les, C.S. Leon and E. John. "Development and Pilot-Scale Demonstration of Deep Cone Paste Thickening Process for Phosphatic Clay Disposal". Phase II. Institute of Phosphate Research, pp. 1-23. 2011.

[4] R. Jewell. "Paste \& Thickened Tailing in the Australian Mining Industry". High Density \& Paste, Seminar Santiago-Chile. 2002.

[5] A.C. de Araujo, C.C. Souza and S.C. Amarante. "Rejeitos Adensados para Disposição em Superfície / Nova Tecnologia em Minério de Ferro". In: IV Simpósio Brasileiro de Minério de Ferro, IV, Ouro Preto. Associação Brasileira de Metalurgia e Materiais, pp. 610-619. 2003.

[6] P. Simms. "On the Relation Between Laboratory Flume Tests and Deposition Angles of High Density Tailings". In Proceedings 10th International Seminar on Paste and Thickened Tailings (Paste 2007). Perth, Australia, pp. 329-335. 2007.

[7] S. Clayton, T.G. Grice and D.V. Boger. "Analysis of the slump test for on-site yield stress measurement of mineral suspensions". International Journal of Mineral Processing, Vol. 70, pp. 3-21. 2003.

[8] R.H. Olcay, G.E.S. Valadão, A.C. de Araujo and C.A. Hernández. Australian Centre for Geomechanics ACG. (Paste 2009). "Development and testing of a laboratory scale paste thickener". Vol. 12, pp. 119-128. Editors: Richard Jewell, Andy Fourie, Sergio Barrera and Jacques Wiertz, Viña del Mar, Chile, 2009.

[9] S. Slottee, J. Jhonson and M. Crozier. "Paste Thickening Iron Ore Tailings". In: XXXV Seminário de Redução de Minério de Ferro e Matérias Primas, VI Simpósio Brasileiro de Minério de Ferro, 30 agosto a 02 setembro de Florianópolis - Santa Catarina-Brasil, pp. 904-911. 2005.

[10] Q.D Nguyen and D. V. Boger. "Application of rheology to solving tailings disposal problems". International Journal of Mineral Processing. Vol. 54. pp. 217-233. 1998.

[11] J. Oxenford and E.R. Lord. "Canadian experience in the application of paste and 
thickened tailings for surface disposal". In: Proceedings 9th International Seminar on Paste and Thickened Tailings (Paste2006), Limerick, Ireland, pp. 93-106. 2006.

[12] R. Summerhaysa and A. Gaspar, "SYMPHOS 2015". 3rd International Symposium on Innovation and Technology in the Phosphate Industry. Thickening, Filtration and Clarification in the Phosphoric Acid Industry, Elsevier ScienceDirect, Procedia Engineering. Vol. 138, pp. 164-173. 2016.

[13] J. Gao and A. Fourie. "Using the flume test for yield stress measurement of thickened tailings". Elsevier, Minerals Engineering, Vol. 81, pp. 116-127. 2015.

[14] N. Q. Dzuy, D.V. Boger, "Yield Stress Measurement for Concentrated Suspensions". Journal of Rheology. Vol. 27, pp. 321-349. 1983.

[15] P. Coussot. "Rheometry of Pastes, Suspensions, and Granular Materials: Applications in Industry and Environment". John Wiley \& Sons. 2005.

[16] J. M. Baker, "Nonlinear rheology of colloidal dispersions", J. of Physics: Condensed matter 22(36): 363101, 2010.

[17] P. Jarvis, B. Jefferson, J. Gregory and S.A. Parsons. "A review of floc strength and breakage". Water Research. Vol. 39 Issue 4, pp. 3121-3137. 2005.

[18] T.S. Patrick, W. Keller and S.E. Pratsinis. "The effect of impeller type on floc size and structure during shear-induced flocculation", Journal of Colloid and Interface Science. Vol. 184 Issue 1, p. 112-122. Article $\mathrm{N}^{\circ} 0601$. 1996.

[19] N. Tambo. "Water Supply". 9, 1, 1991.

[20] J.R. Stokes and J.H. Telford. "Measuring the yield behavior of structures fluids". J. Non-Newtonian Fluid Mechanics. Vol. 124, pp. 137-146. 2004.

[21] Q.D. Nguyen and D.V. Boger. "Measuring the flow properties of yield stress fluids". Annu. Rev. Fluid Mech. Vol. 24, pp. 47. 1992.

[22] H.A. Barnes and J.O. Carnali. "The vanein-cup as a novel rheometer geometry for shear thinning and thixotropic materials", J. Rheol. Vol. 34 Issue 6, pp. 841. 1990.

[23] D.V. Boger. "Environmental rheology and the mining industry". Proceedings of the
Sixth International Symposium on Mining with Backfill. The Australasian Institute of Mining and Metallurgy Publication Series, Brisbane, Australia, pp. 15-17. 1998.

[24] S. Clayton, T.G. Grice and D.V. Boger. "Analysis of the slump test for on-site yield stress measurement of mineral suspensions". International Journal of Mineral Processing. Vol. 70, pp. 3-21. 2003.

[25] D.V. Boger. "Rheology and the minerals industry". Minerals Processing Extractive Metallurgy. Rev. 20, pp. 1-25. 2000.

[26] D.V. Boger. "Rheology of slurries and environmental impacts in the mining industry". Annual review of chemical and biomolecular engineering. Vol. 4, pp. 239257. 2013.

[27] D.V. Boger. "Rheology and the resource industries". Chemical Engineering Science, Vol. 64, pp. 4525-4536. 2009.

[28] F. Sofrá, and D.V. Boger. "Environmental rheology for waste minimisation in the minerals industry". Chemical Engineering, J. Vol. 86, pp. 319-330. 2002.

[29] S.K.Y. Gawu and A.B. Fourie. "Assessment of the modified slump test as a measure of the yield stress of high-density thickened tailings". Can. Geotech. J. Vol. 41, pp. 39-47. 2004.

[30] A. Fourie. "Materials Characterics". In: High Density \& Paste, Seminar, Apresentações digitais Melbourne - Austrália. 2003. URL: http://www.tailings.info/disposal/paste.htm

[31] R.H. Olcay, A.C de Araujo and G.E.S. Valadão. "Seleção de floculantes en estudo de espessador de pasta de laboratorio". XXIII Encontro Nacional de Tratamento de Minérios e Metalurgia Extrativa, Gramado Rio Grande do Sul, Brasil. 2009.

[32] J. Rubio, E. Carissimi and J. D. Miller. "Characterization of the High Kinetic Energy Dissipation of the Flocs Generator Reactor (RGF)". International Journal of Mineral Processing, Vol. 85, pp. 41-49. 2007.

[33] P. Newman, R. White and A. Cadden, "Paste - The Future of Tailings Disposal?". III International Seminar of High Density and Paste Tailings, Apresentações digitais Pilanesburg - South Africa. May 2001. URL: http://citeseerx.ist.psu.edu/viewdoc/downloa $\mathrm{d}$ ?doi=10.1.1.527.931\&rep=rep1\&type=pdf 